\title{
PERSEPSI CITRA VISUAL DAN PENGARUH BYSTANDER EFFECT TERHADAP KEHIDUPAN SOSIAL DI MASYARAKAT
}

\author{
Sultan Adik Arrohim Zaedy ${ }^{1)}$, Ade Setiawan ${ }^{2)}$, Tommy Iriansyah $^{3)}$ \\ Program Studi Desain Komunikasi Visual, \\ Fakultas Bahasa dan Seni, Universitas Indraprasta PGRI \\ Jl. Nangka 58 C Tanjung Barat, Jakarta Selatan, 12530, Indonesia
}

Email: adieksultan@gmail.com

\begin{abstract}
Abstrak
Dalam kehidupan sehari-hari, sebagai masyarakat tentunya pernah melihat kerjadian darurat di tempat umum seperti kecelakaan, perampokan, dan sebagainya. Pada umumnya, rasa empati yang tertanam pada diri manusia akan bergegas menolong korban dari situasi kritis tersebut. Namun, para psikolog menyarankan masyarakat untuk menilai turut campur tangannya seseorang akan kejadian darurat tersebut bergantung pada jumlah saksi lain yang hadir di lokasi terebut. Banyaknya saksi akan memunculkan perasaan ragu terhadap seseorang untuk menunjukan rasa empatinya atau tidak. Istilah ini disebut dengan Bystander Effect. Penelitian ini dilakukan untuk mengetahui hubungan antara bystander effect dengan perilaku sosial pada kehidupan bermasyrakat yang sudah memasuki zaman post-modern ini. Teknik pengumpulan data dalam artikel ini ialah dengan menggunakan studi literatur. Selain itu artikel ini juga membahas kasus tentang bystander effect terhadap perilaku sosial masyarakat dan mengkaji dengan kajian persepsi citra sebagaimana pada ilmu citra visual. Hasil dari penelitian ini akan menjadi peringatan masyarakat akan bentuk kepedulian, tidak hanya bersimpati tetapi juga berempati, mengurangi sifat apatisme dan meningkatkan kewaspadaan terhadap situasi-situasi yang memiliki kemungkinan terjadinya keadaan darurat di tengah keramaian.
\end{abstract}

Kata Kunci: Bystander effect, Perilaku sosial, Simpati, Empati

\begin{abstract}
In everyday life, surely as a community, of course, have seen emergency work in public places such as accidents, robberies, and so on. In general, empathy embedded in human beings will rush to help victims of this critical situation. However, psychologists advise the public to judge whether a person's intervention in the emergency event depends on the number of other witnesses present at the location. A large number of witnesses will give rise to feelings of doubt towards someone to show their empathy or not. This term is called the Bystander Effect. This research was conducted to determine the relationship between the bystander effect and social behavior in social life that has entered this post-modern era. The sampling technique in this article is to use the literature study technique. Another method in this research is to study examples of cases that often occur about the bystander effect on social behavior and studied with the study of imagery perception as in visual imagery. The results of this study will be a warning to the public about the form of concern, not only sympathizing but also empathizing, reducing the nature of apathy, and increasing awareness of situations that have the possibility of emergencies in a crowd.
\end{abstract}

Keywords: Bystander effect, social behaviour, sympathy, empathy

Correspondence author: Sultan Adik Arrohim Zaedy, adieksultan@gmail.com, Jakarta, Indonesia 


\section{PENDAHULUAN}

Dalam kehidupan sosial masyarakat pada umumnya seseorang akan membutuhkan bantuan dari orang lain. Yang artinya sebagai manusia pasti membutuhkan manusia lainnya. Dari sini muncul istilah simpati dan empati yang menjelaskan sikap kepeduliaan seseorang terhadap orang lain. Menurut Knight pada Siti Hawa Abdullah (2007), istilah "empati" tercetus daripada idealisme di Jerman pada lewat abad ke-19. Empati atau dalam bahasa Jermannya "einfuhlung" bermaksud merasakan (feeling into) dan berasal daripada perkataan Yunani "empatheia", iaitu gabungan perkataan "em" yang bermakna dalam (in) dan "pathos" yang bermakna perasaan (feeling). Oleh sebab sifatnya (merujuk kepada emosi), empati lebih mendapat perhatian ahli psikologi, terutama mereka yang mengkaji perkembangan perlakuan sosial. Solomon dkk melaporkan program latihan empati yang dibentuk oleh beberapa pengkaji dalam tahun 1970-an dan 1980-an yang mana para pengkaji tersebut melihat empati sebagai mekanisme perantaraan penting bagi pemupukan perlakuan prososial dan penghalang agresi, lantas pendekatan latihan empati yang mereka gunakan merangkumi kedua aspek afektif dan kognitif (Abdullah \& Hassan, 2007).

Menurut Eisenberg dalam Muhrima (2010) empati adalah kondisi emosi dimana seseorang merasakan apa yang dirasakan orang lain seperti dia mengalaminya sendiri, dan apa yang dirasakannya tersebut sesuai dengan perasaan dan kondisi orang yang bersangkutan. Meskipun empati merupakan respon yang bersifat emosi namun juga melibatkan ketrampilan kognitif seperti kemampuan untuk mengenali kondisi emosi orang lain dan kemampuan mengambil peran. Empati diukur dengan melakukan tes dimana kepada anak disajikan cerita atau rangkaian gambar yang mengandung informasi tentang kondisi perasaan orang lain (misalnya anak yang menangis ditinggal ibunya pergi). Kemudian mereka diminta memberi respon, verbal atau nonverbal (dengan menunjuk gambar ekspresi wajah) tentang apa yang mereka rasakan. Anak-anak tersebut akan diberikan skor empatis jika mereka menunjukkan perasaan yang sama dengan situasi tokoh yang ditunjukkan. Beberapa teori menyatakan bahwa empati dan simpati adalah faktor yang sangat penting dalam munculnya perilaku prososial. Gagasan tersebut telah banyak diuji secara sistematis, dan telah didukung banyak bukti empiris. Temuan yang sangat jelas menunjukkan peran empati dan perilaku prososial adalah hasil penelitian yang dilakukan terhadap sekelompok subjek dewasa. Salah satu penelitian adalah yang dilakukan oleh Toi dan Batson (Muhrima, 2010).

Dalam kehidupan sehari-hari serta beraktivitas di tempat umum, seseorang sebagai masyarakat pasti lah pernah mengalami kejadian buruk yang tidak terduga seperti hal kejadian darurat perampokan, kecelakaan, hingga hal-hal buruk lainnya. Sebagai masyarakat yang selalu aktif bersosial pasti muncul rasa simpati hingga empati terhadap korban kejahatan tersebut yang membuat seseorang berpikir harus mengambil tidakan berupa bantuan sekecil apa pun itu agar korban dapat tertolong. Misal kejadian pada kecelakaan, ketika seseorang melihat orang lain mengalami kecelakaan maka dengan sigap muncul perasaan empati ingin menolong korban. Akan tetapi di satu sisi ada beberapa orang yang melihat kejadian itu dikarekankan kejadian berlangsung ditengah keramaian jalan raya. Ketika seseorang melihat adanya orang lain yang menjadi saksi, maka akan muncul keraguan dibenak orang tersebut bahwa ia tidak perlu menolong karena sudah ada orang lain yang dapat menolong. Keputusan orang tersebut atas munculnya dua pilihan yang membuat keraguan ini berdampak besar terhadap perilaku sosial orang itu ke depannya. Istilah ini biasa disebut dengan Bystander effect.

Secara harfiah, bystander adalah istilah psikologi yang berarti penonton dalam suatu kondisi. Cherry menyatakan bahwa bystander effect merupakan penurunan intensitas perilaku menolong dalam situasi yang membutuhkan pertolongan disebabkan karena terdapat banyak individu lain yang berada dalam situasi tersebut (Cherry dalam Nurhalizah, 2019). Bystander effect adalah orang-ora ng yang berada di sekitar tempat kejadian dan mempunyai peran sangat besar dalam mempengaruhi seseorang saat memutuskan antara menolong atau tidak ketika dihadapkan pada keadaan darurat (Sarwono dalam Nurhalizah, 2019).

Menurut Nurhalizah, bystander effect ialah situasi atau keadaan di mana orang hanya menjadi pengamat, tidak melakukan apapun untuk membantu atau menolong, dalam keadaan 
darurat individu lebih cenderung cepat memberikan respon apabila sendirian dari pada dalam keadaan ramai, karena mereka beranggapan bahwa orang lain juga mengetahui situasi tersebut, semakin banyak orang yang hadir, maka semakin kecil orang benar-benar memberikan pertolongan (Nurhalizah, 2019).

Dari contoh kasus serta beberapa pengertian di atas, dapat disimpulkan bahwa bystander effect dapat mempengaruhi perilaku sosial yang buruk karena dinilai apatis dan tidak peduli. Dalam hal ini biasanya seseorang akan kurang prososial efek dari bystander. Ada beberapa faktor yang mempengaruhi bystander effect menurut Sarwono dalam Komsiya dan Triningtyas (2019), yaitu: Pengaruh sosial (social influence); Hambatan penonton (audience inhibition); Penyebaran tanggung jawab (diffusion of responsbility). Individu yang kurang memiliki perilaku prososial akan menunjukkan motif ketika menolong. Motif tersebut merupakan salah salah satu dari bentuk presentasi diri (Nurhalizah, 2019).

\section{METODE PENELITIAN}

Metode penelitian yang penulis lakukan brkaitan dengan bystander effect ini adalah dengan studi literatur dan mempelajari contoh kasus yang ada. Pendekatan yang digunakan dalam penelitian ini yaitu pendekatan kualitatif dan juga metode penelitian deskriptif. Menurut Kirk dan Miller dalam Barlian (2016) penelitian kualitatif adalah tradisi tertentu dalam ilmu pengetahuan sosial yang secara fundamental bergantung dari pengamatan pada manusia baik dalam kawasannya maupun dalam peristilahannya. Penelitian deskriptif (descriptive research) yang dilakukan untuk menjawab petanyaan yang berkaitan dengan status objek penelitian pada saat penelitian diadakan, atau dengan kata lain, menginformasikan keadaan sebagaimana adanya (Barlian, 2016). Penulis akan mengkualifikasi masyarakat yang terkena dampak bystander effect secara positif dan negatif. Pengumpulan data yang digunakan pada penelitian ini menggunakan random sampling dengan mengumpulkan data dan contoh kasus dari situs daring terpercaya. Selanjutnya penulis akan mengkaji objek bystander effect dengan kajian atau keilmuan desain komunikasi visual tentang persepsi citra visual dari apa yang masyarakat lihat hingga muncul dalam benak masyarakat tentang bagaimana pandangan, mitos, hingga realitas yang mereka rasakan setelah menjadi pengamat suatu kejadian kritis.

\section{HASIL DAN PEMBAHASAN}

Penelitian dari dampak bystander effect yang penulis lakukan dengan mempelajari kasus-kasus yang ada serta dari literatur yang membahas objek serupa tentang bystander effect, penulis mendapatkan hasil sebagai berikut.

\section{Hasil}

Pada contoh kasus yang penulis alami, ketika terjadi suatu situasi kritis pada seseorang di jalan raya, sikap empati orang terdekat yang akan sigap mengambil keputusan untuk menolong. Biasanya meski pun pengendara dibelakang korban melihat jelas kejadian, dengan melihat sekitar ketika mulai banyak saksi lain, pengendara yang pertama kali melihat kejadian bahkan melihat secara rinci pun akan pergi meninggalkan korban. Ada beberapa faktor yang mempengaruhi orang tersebut menjadi bystander. Hal yang paling umum adalah ketika seseorang merasa terburu-buru, ia lebih cenderung untuk bersifat apatis dan tidak memperdulikan apa yang baru saja ia lihat. Akan tetapi berbeda ketika orang tersebut meninggalkannya karena melihat ada orang lain juga di tempat kejadian yang menjadi saksi kejadian tersebut. Hal ini akan menimbulkan keraguan seseorang untuk mengambil tindakan menolong. Seseorang akan merasa kehadiran orang lain cukup untuk menolong korban yang bahkan belum tentu melihat kejadiannya secara rinci dibanding orang yang pergi meninggalkan korban. Dari hal tersebut akan memunculkan sikap baru, kebiasaan baru, hingga budaya baru ketika masyarakat saling mengandalkan orang lain untuk menolong korban yang berada dalam situasi kritis. Pengaruhnya pada perilaku sosial masyarakat yang sempat terjadi ketika pandemi COVID-19, hal tersebut menjadi sangat memprihatinkan. Ketika seseorang jatuh atau mengalami kecelakaan di tengah keramaian, orang-orang hanya akan jadi pengamat dan melihat 
kejadian serta saling mengandalkan orang yang ada di sekitarnya untuk menolong korban. Di sisi lain rasa takut akan tertularnya virus memperkuat masyarakat menjadi orang yang apatis. Menunggu orang lain memulai, saling mengandalkan, bahkan hingga petugas medis atau kepolisian mulai menolong, masyarakat baru akan tergugah hatinya untuk ikut menolong. Sisanya hanya akan melihat lalu pergi. Kebiasaan ini muncul dari adanya bystander effect sebelum adanya pandemi COVID-19.

Akan tetapi, dampak dari bystander effect ini juga terdapat pengaruh baik atau positif sehingga seseorang akan meningkatkan kewaspadaannya untuk tidak mengalami situasi buruk di tengah keramaian akibat rasa takut akan tidak ada yang menolong. Meski terdapat seratus orang pun, karena orang tersebut sudah mengatahui adanya orang-orang apatis akibat bystander, orang tersebut akan lebih menjaga dirinya sendiri.

Lalu penulis mencoba menguji bystander effect dengan menjadi korban, bukan pada situasi kritis tapi dapat dikatakan cukup darurat. Contoh ini penulis ambil dari kasus kecil pada sebuah grup obrolan whatsapp. Ketika dalam satu grup ada yang bertanya atau dapat dikatakan membutuhkan pertolongan meski pun dalam kondisi darurat, biasanya anggota grup akan tetap mengamati atau melihat pesan pertanyaan tersebut akan tetapi mereka bersikap apatis dengan harapan dengan banyaknya anggota akan ada jawaban dari anggota lain. Biasanya faktor ketakutan salah menjawab dan ketika ada orang lain yang menjawab benar ia akan merasa malu. Hal ini membuatnya lebih memilih menjadi seorang pengamat dan memunculkan pengamatpengamat lain akibat dari bystander effect pada kasus serupa.

Dari banyaknya kasus bystander effect hingga era post-modern ini, memunculkan perilaku baru, yaitu simpati untuk presentasi diri. Beberapa kasus yang sudah cukup banyak masyarakat ketahui, era serba teknologi ini menjadikan setiap orang memiliki gawai dengan teknologi kamera dan internet yang baik. Para pengamat akibat bystander effect yang sebelumnya hanya mengamati lalu menjadi apatis, sekarang justru memanfaatkan situasi kritis untuk presentasi diri. Contoh kasus lain ada suatu kejadian kecelakaan atau perampokan, banyaknya saksi di sekitar akan membuat orang menjadi pengamat, mengandalkan orang lain yang menolong, lalu saksi lain dalam situasi bystander akan merasa simpati dan melakukan dokumentasi untuk menyebarkan informasinya melalui gawai dan sosial media mereka. Dalam kasus ini, anggap mereka memuat dokumentasi tersebut menjadi sebuah konten agar mendapat banyak komentar baik untuk korban, lalu penyebar konten tersebut akan kebanjiran komentar dan 'like' pada unggahannya. Hal tersebut akan menjadi peluang bagi penyebar konten untuk mempresentasikan dirinya lebih baik di pandangan teman-teman sosial medianya. Meski pun niat awalnya baik dengan bersikap simpati agar korban mendapat banyak doa baik dan juga informasi tersebar dengan cepat sebelum adanya media berita televisi, akan tetapi jika ia hanya menjadi pengamat yang mendokumentasikannya tanpa menolongnya atau mengandalkan saksi lain untuk menolongnya, hal ini akan menjadi perilaku sosial yang buruk. Kebiasaan perilaku sosial pada era serba teknologi ini menjadikan penilaian orang terhadap masyarakat saat ini menjadi tidak baik. Orang-orang saat ini akan menjadi lebih apatis terhadap kejadian darurat seperti itu karena mereka tidak ingin terkena dampak bystander effect yang memuat konten seperti pada contoh kasus di atas. 


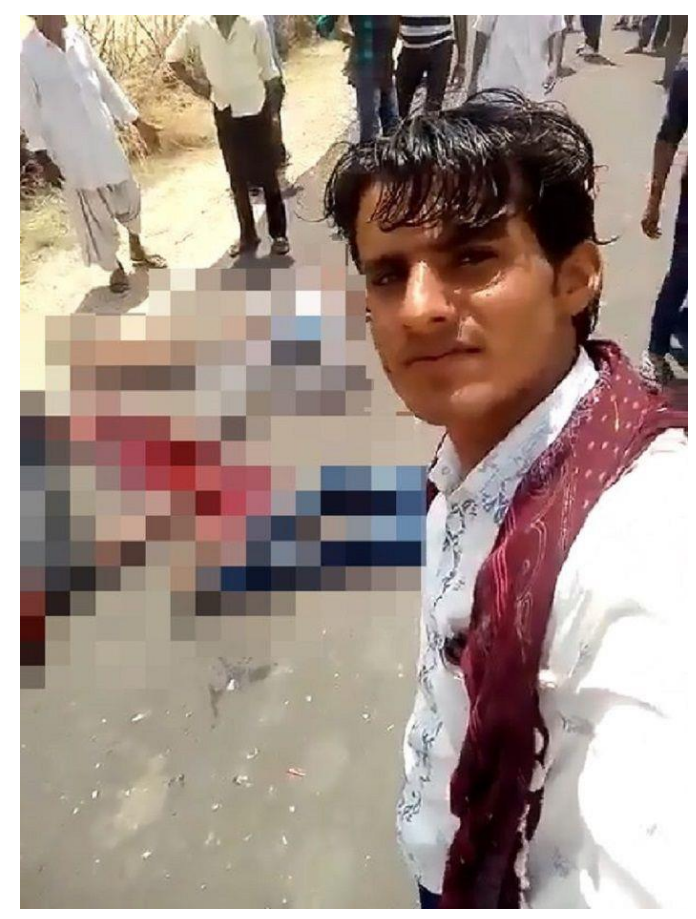

Gambar 1 Contoh bystander effect dengan memuat konten Sumber: nakita.grid.id

\section{Pembahasan}

Pada penelitian ini, penulis akan mengkaji kejadian perilaku sosial masyarakat yang terkena bystander effect dengan konten dokumentasi melalui media sosial. Kajian yang penulis gunakan adalah kajian pada ilmu desain komunikasi visual yaitu kajian persepsi citra dengan tiga jenis persepsi citra yang bebeda, simulakra, mitos, dan pandangan.

Posmodernisme hadir dengan mengusung kepalsuan dan hal-hal semu yang sering kali berada pada garis abu-abu logika seseorang. Lyotard menyatakan bahwa zaman posmodernisme ini merupakan sebuah masa di mana orang meragukan metanarasi, meniadakan sistem-sistem filosofis yang lampau, dan menciptakan narasi-narasi mikro sesuai versi masing-masing individu. Pada zaman ini semua serba ada, tersedia, dan bebas karena posmodernisme menganut paham kebebasan. (Arsita, 2018)

Melihat citra secara kritis dari realitas fotografi dokumentasi hasil dari bystander effect yang sudah penulis jelaskan, dapat menimbulkan persepsi yang berbeda pada masyarakat. Terlebih lagi era posmodernisme kini semakin banyak orang yang lebih berhati-hati terhadap pemberitaan palsu atau informasi hoax. Citra visual konten simpati dari korban kecelakaan yang di unggah oleh pelaku bystander effect ini dapat memberikan dampak buruk, hal yang sebenarnya terjadi bisa dianggap palsu atau buatan dengan alasan pengunggah melakukannya demi presentasi diri dan popularitas (viral). Anggapan atau persepsi tersebut dapat dibagi menjadi beberapa bagian, yang pertama adalah persepsi citra visual simulacra baudrillard.

Simulakra adalah bagian dari teori semiotika yang diungkapkan oleh Jean Baudrillard. Baudrillard berpendapat bahwa tanda telah jauh dipisahkan dari objek yang direpresentasinya, dan media seolah menggiatkan proses pemisahan tersebut hingga ambang nihilisme. Seharusnya sebuah tanda secara sederhana dapat merepresentasi suatu objek tertentu (Arsita, 2018). Pada konten yang diunggah oleh pelaku bystander effect, realitas sebenarnya adalah rasa simpati orang tersebut terhadap korban yang membutuhkan dukungan dan doa dari masyarakat agar korban merasa tertolong dan dipedulikan secara sosial. Akan tetapi realitas lain bagi pengguna sosial media yang melihat bahkan bagi korban sendiri belum tentu seperti itu. Realitas yang ada dapat membagi persepsi menjadi berbagai persepsi yang berbeda. Bagi korban bisa saja ia merasa kesal karna dirinya sebagaimana privasi yang ia jaga sendiri saat kondisi kritis atau tidak 
mampu mengendalikan dirinya, malah diunggah secara publik oleh orang yang bahkan tidak ia kenal, hanya sebatas pengamat, bahkan tidak menolong sama sekali. Bagi pemirsa yang menyaksikan secara virtual melalui media sosial, bisa memberikan persepsi berbeda ditambah jika pengunggah tidak memberikan informasinya secara jelas dan rinci tentang kejadian tersebut, kondisi korban, waktu dan tempat, dan sebagainya. Pemirsa dapat menilai realitas itu palsu, bisa menilai realitas itu nyata sesuai dengan tanda yang ada, misal pada fotografi visual terlihat siang hari, keadaan korban penuh luka, dan semacamnya, pemirsa dapat menilai realitas sesuai dengan apa yang mereka lihat dari tanda yang ada pada konten visual tersebut.

Jika dilihat dari sisi mitos dan pandangan, mitos yang terdapat pada konten tersebut menunjukan bahwa kejadian itu sangat mengharukan, seseorang yang ada di lokasi kejadian bisa sangat ramai dan kondisi haru juga kasihan pada korban. Meski realitas sebenarnya korban hanya mendapat luka kecil. Lalu jika dilihat dari sudut pandang secara sensual (the male gaze), seseorang akan merasa tidak nyaman dengan konten tersebut, merasa konten tersebut bukanlah sesuatu yang harus ditunjukan kepada publik. Berbeda jika dilihat dari sudut pandang emosional (the female gaze), konten tersebut akan memberikan reaksi emosional yang mengharukan, menyedihkan hingga memprihatinkan. Dari semua penjelasan kajian tersebut, menyatakan secara garis besar pelaku bystander yang melakukan dokumentasi pada saat kejadian kritis berlangsung. Penulis akan melakukan penelitian lain dengan mengambil salah satu contoh kasus yang ada di Indonesia bertepatan dengan kasus seorang influencer dan juga pemusik yang cukup dikenal sebagian masyarakat, yaitu Reza 'Arap' Oktovian dari grup musik Weird Genius.

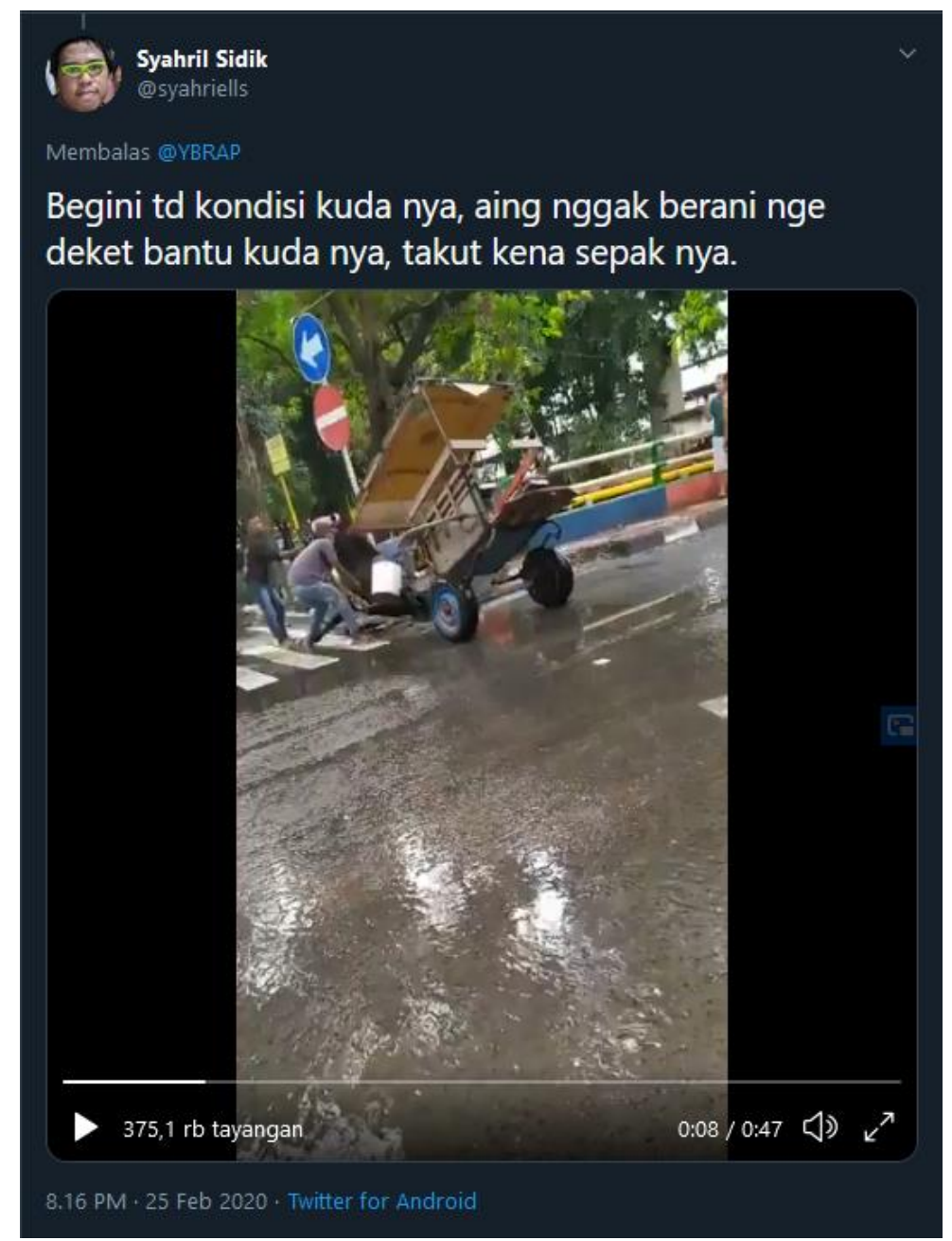

Gambar 2 Video kuda ‘delman’ yang kelelahan menarik andong Sumber: twitter.com/syahriells 
Dalam video unggahan Syahril Sidik, menunjukan sebuah kejadian yang dialami hewan yang dikenal kuat untuk menarik beban. Akan tetapi pada dasarnya hewan juga memiliki batas kekuatan dan dapat merasakan lelah. Dikutip dari sebuah artikel daring suara.com (2020), kuda berwarna hitam mengamuk di pinggir jalan saat beberapa orang berusaha melepas tali yang mengaitkan kereta delman dengan bagian belakang kuda. Rupanya, kuda itu kelelahan selepas mengangkut warga yang terkena banjir (Gunadha \& Intan, 2020). Syahril Sidik yang merekam kejadian tersebut, dalam cuitannya mengaku tidak berani membantu karena rasa takut yang ia rasakan jika kuda yang dipaksa tersebut akan mengamuk. Syahrul Sidik sebagai pengamat (bystander) merekam kejadian tersebut lalu mengunggahnya di Twitter pada balasan sebuah ulasan dari Reza Arap.

\section{gua barusan hampir digebukin massa gegara mau nolongin kuda delman yang kecapean sampe jato. orang2 amukin gua karena gua berentiin mobil tepat di sebelahnya dan berpikir gua cuma mau foto. gua turun gua bacotin 1 area karena mereka cuma liatin tp nga nolongin.}

\subsection{PM - 25 Feb 2020 - Twitter for iPhone}

\section{4,9 rb Retweet $\quad 47,6$ rb Suka}

Gambar 3 Cuitan Reza Arap menjelaskan rinci kejadian. Sumber: suara.com

Dalam sebuah utas pada sosial media Twitter milik Reza Arap, ia menjelaskan secara rinci kejadian yang ia alami saat itu (25/02/2020). Dalam utasnya ia memberikan pembelaan atas dirinya yang dianggap melakukan tindak negatif bagi sebagian saksi yang melihat kejadian tersebut. Dikutip dari suara.com (2020), Reza Arap hampir dikeroyok massa saat hendak menyelamatkan kuda delman yang kelelahan mengangkut warga Jakarta yang terkena banjir. Lewat akun Twitter@YBRAP, pria yang pernah mendonasikan akun Youtube-nya itu membeberkan kronologi cerita. Reza yang saat itu tengah melintas di wilayah dekat tempat kejadian sengaja menepi di sebelah kuda karena berniat menolong binatang malang tersebut. Ia menyesal karena pada saat kejadian tak membawa uang tunai yang cukup banyak untuk membeli kuda tersebut (Gunadha \& Intan, 2020).

Dari kasus tersebut dan penjelasan Reza Arap, penulis mengambil kesimpulan bahwa sebagian besar saksi yang ada di lokasi kejadian sebagai pengamat (bystander) menilai yang dilakukan Reza Arap ini hanya tindakan membuat konten dengan mendokumentasikan kuda malang itu. Pikiran negatif yang mereka keluarkan ini termasuk dampak dari bystander effect. Kebanyakan orang di situ melakukan rekam peristiwa termasuk Syahril Sidik yang mengunggah video rekamannya. Berbeda dengan Syahril, sebagian saksi geram melihat Reza yang turun dari mobilnya yang ia hentikan di tengah jalan dengan menduga Reza akan mengambil foto kejadian, padahal realitanya Reza ingin menolong kuda tersebut. Akibatnya, sempat terjadi keributan sehingga membuat jalanan macet saat itu. 


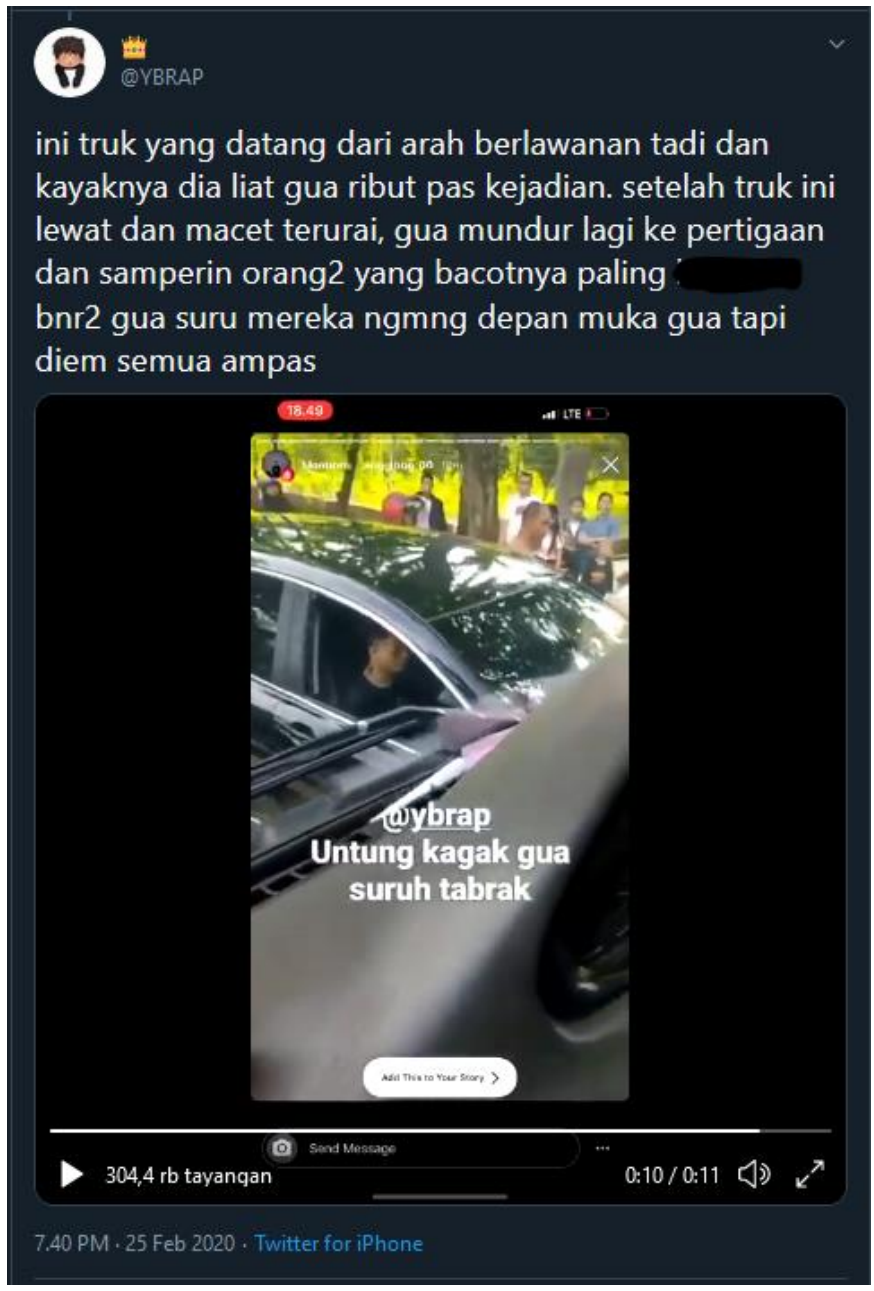

Gambar 4 Video dokumentasi supir truk yang melintas terjebak macet Sumber: twitter.com/YBRAP

Supir truk sebagai pengamat (bystander) merekam video Reza Arap yang sedang emosi dan memindahkan mobilnya ke tempat yang lebih aman untuk pengguna jalan. Pada video tersebut, terlihat banyaknya jumlah saksi yang ada tetapi hanya sebagian kecil yang melakukan tindakan membantu Reza Arap dan juga tragedi kuda tersebut. Sebagian besar hanya sebagai pengamat dan melakukan rekam peristiwa dengan memotret menggunakan gawainya. Yang masyarakat lakukan saat itu tidak lain adalah dampak dari bystander effect. Supir truk dan Syahril Sidik yang merekam mendapatkan notice dari Reza Arap dan mendapatkan Retweet dan Likes yang cukup banyak. Di lihat dari komentar warga net Twitter setelah membaca penjelasan Reza Arap, sebagian besar geram melihat tindakan warga di lokasi kejadian. Hal ini lah yang menjadikan perbedaan persepsi ketika seseorang melihat suatu kejadian dengan sudut pandang yang berbeda.

Penulis menarik kesimpulan perbedaan persepsi oleh beberapa pihak. Dari pihak warga sebagai saksi, ketika melihat kejadian kuda, mereka hanya mengamati karena menganggap dua orang pria yang kesulitan melepas kait kuda dapat membereskan kejadian. Dan ketika Reza Arap datang dengan statusnya sebagai influencer, saksi yang melihat justru menilai Reza ingin mengambil kesempatan dengan mendokumentasikan kejadian tragis tersebut. Ketika kericuhan terjadi dan Reza mulai berteriak melawan, sebagian orang termasuk Syahril Sidik pria berbaju putih yang dijelaskan Reza Arap pada utasnya, berusaha menenangkan emosi Reza dan mulai bertindak mencairkan suasana yang cukup panas saat itu. Jika dilihat dari sudut pandang supir truk yang melintas tanpa mendengarkan apa yang sedang terjadi, ia menilai Reza Arap emosi 
dan memarahi warga sekitar (pembicaraan supir truk dalam video). Dan jika dilihat dari sudut pandang warga net yang telah membaca kejadian melalui utas Reza, justru menilai warga di lokasi kejadianlah yang salah persepsi dengan menilai buruk terhadap Reza Arap. Warga net juga sempat mengkhawatirkan akan muncul dokumentasi lain dengan sudut pandang dan cerita yang berbeda dengan yang Reza Arap jelaskan. Perbedaan persepsi ini yang menjadikan konten informasi seperti itu harus dilihat dari berbagai sudut pandang. Jika masyarakat melihat dari satu sudut pandang saja, simulasi dan persepsi dari realitas visual yang ia lihat akan berbeda dengan realitas sesungguhnya.

Bystander effect ini sangat berbahaya karena akan menimbulkan banyaknya persepsi pada interpretasi visual yang ada. Masyarakat diharapkan melihat suatu citra secara kritis sebelum menilai citra tersebut. Solusi yang dapat penulis sarankan untuk permasalah ini adalah dengan memahami suatu citra pada suatu kejadian sebelum melakukan interpretasi visual. Kebiasaan masyarakat dalam menilai sesuatu dari apa yang tampak secara visual harus dikurangi dengan mulai melihat segala sesuatunya secara kritis. Berpikir sebelum menilai sesuatu. Melihat suatu citra dari berbagai sudut pandang. Tidak mengambil kesimpulan sendiri dengan persepsi yang hanya dilihat dari satu sudut pandang saja.

\section{SIMPULAN}

Bystander effect adalah situasi atau keadaan di mana orang hanya menjadi pengamat, tidak melakukan apapun untuk membantu atau menolong, dalam keadaan darurat individu lebih cenderung cepat memberikan respon apa bila sendirian dari pada dalam keadaan ramai, karena mereka beranggapan bahwa orang lain juga mengetahui situasi tersebut, semakin banyak orang yang hadir, maka semakin kecil orang benar-benar memberikan pertolongan. Pada era posmodernisme ini, orang yang menjadi pengamat akan lebih memprihatinkan dibandingkan dengan sebelumnya yang hanya tidak menolong. Pengamat atau pelaku bystander malah akan mendokumentasikan kerjadian darurat tersebut untuk dijadikan konten. Meski terkadang dampak yang terjadi baik dengan banyaknya orang merasa iba dan berdoa untuk korban, tetapi akan menjadi buruk jika korban tidak menerima dirinya dieksploitasi secara publik.

Menurut pandangan ilmu desain komunikasi visual tentang persepsi citra visual, konten dari pelaku bystander effect ini dapat memberikan persepsi citra yang berbeda dari realitas yang terjadi secara nyata. Dapat memberikan persepsi baik dan dapat memberikan persepsi buruk terhadap citra visual yang ditampilkan.

Dari penelitian ini, penulis mengharapkan masyarakat agar lebih prososial dalam menolong meski pun dinilai dengan adanya orang yang banyak atau keramaian terkadang korban merasa sesak, akan tetapi jika merasa seperti itu akan lebih baik jika memberi simpati lalu pergi seperti bertindak apatis. Jangan melakukan dokumentasi tanpa izin dari korban yang dieksploitasi. Belum tentu semua orang sebagai korban akan merasa nyaman dengan kondisi seperti itu.

\section{DAFTAR PUSTAKA}

Abdullah, S. H., \& Hassan, A. (2007). Empati sejarah dalam pengajaran dan pembelajaran sejarah. Malaysian Journal of Educators and Education, 22, 61-74. Retrieved from http://www.usm.my/education/publication/JPP SITI HAWA \& AINI ART 4 (61-74).pdf

Arsita, A. (2018). Simulakra Baudrillard dalam multidimensi posmodernisme: Kajian fotografi makanan dalam media sosial instagram. REKAM: Jurnal Fotografi, Televisi, dan Animasi, 13(2), 85. https://doi.org/10.24821/rekam.v13i2.1932

Barlian, E. (2016). Metodologi penelitian kualitatif \& kuantitatif. https://doi.org/10.31227/osf.io/aucjd

Chozanah, R. (2018). Viral, Pria ini selfie di depan korban kecelakaan yang sebenarnya masih 
bisa diselamatkan! Retrieved June 23, 2020, from https://nakita.grid.id/read/02898927/viral-pria-ini-selfie-di-depan-korban-kecelakaanyang-sebenarnya-masih-bisa-diselamatkan?page=all

Gunadha, R., \& Intan, R. (2020). Niat selamatkan kuda delman, Influencer Reza Arap hampir dikeroyok massa. Retrieved July 1, 2020, from Arkadia Digital Media website: https://www.suara.com/news/2020/02/26/132714/niat-selamatkan-kuda-delmaninfluencer-reza-arap-hampir-dikeroyok-massa

Muhrima, A. K. (2010). Empati dan perilaku prososial pada anak. Jurnal Inovasi, 7(3), 1-5. Retrieved from http://ejurnal.ung.ac.id/index.php/JIN/article/download/771/714

Nurhalizah. (2019). Hubungan antara bystander effect dengan perilaku prososial pada mahasiswa fakultas psikologi Universitas Medan Area. Universitas Medan Area.

Oktovia, R. (2020). Tangkapan layar cuitan twitter Reza Arap oleh penulis. Retrieved July 1, 2020, from Twitter @ YBRAP https://twitter.com/YBRAP/status/1232284211 786072065

Sidik, S. (2020). Tangkapan layar cuitan twitter Syahril Sidik oleh penulis. Retrieved July 1, 2020, from Twitter @ syahriells https://twitter.com/syahriells/status/123229326461 2454401 